\title{
Latcripin-13 domain induces apoptosis and cell cycle arrest at the G1 phase in human lung carcinoma $A 549$ cells
}

\author{
JIA WANG ${ }^{1}$, XIANYAO WAN ${ }^{1}$, YIFAN GAO $^{2}$, MINTAO ZHONG $^{2}$, LI SHA $^{2}$, BEN LIU $^{2}$, \\ WEI ZHANG ${ }^{2}$, LI TIAN ${ }^{2}$, WENJING RUAN ${ }^{2}$, SHUYUN CAO $^{2}$ and MIN HUANG ${ }^{2}$ \\ ${ }^{1}$ Department of Critical Care Medicine, The First Affiliated Hospital of Dalian Medical University, Dalian, Liaoning 116021; \\ ${ }^{2}$ Department of Microbiology, Dalian Medical University, Dalian, Liaoning 116044, P.R. China
}

Received January 5, 2016; Accepted February 15, 2016

DOI: $10.3892 /$ or.2016.4830

\begin{abstract}
Latcripin-13 domain, isolated from the transcriptome of Lentinula edodes $\mathrm{C}_{91-3}$, contains a regulator of chromosome condensation (RCC1) domain/ $\beta$-lactamase-inhibitor protein II (BLIP-II) and a plant homeodomain (PHD). Latcripin-13 domain has been shown to have antitumor effects. However, the underlying molecular pharmacology is largely unknown. We report here that Latcripin-13 domain induced cell cycle arrest in the G1 phase and caused the apoptosis of human lung carcinoma A549 cells via the GSK3 $\beta$-cyclin D1 and caspase-8/ $\mathrm{NF}-\kappa \mathrm{B}$ signaling pathways. Western blot analysis showed that Latcripin-13 domain decreased cyclin D1 and cyclin-dependent kinase 4 (CDK4), while it increased the ratio of GSK3 $\beta$ / phosphorylated GSK $3 \beta$. Importantly, Latcripin-13 domain induced nuclear fragmentation and chromatin condensation in the A549 cells. In addition, treatment of the A549 cells with Latcripin-13 domain resulted in the loss of mitochondrial membrane potential, accompanied by an increase in the Bax/ Bcl-2 ratio and activation of caspase-3, -8, and -9. Intriguingly, western blot analysis revealed that $\mathrm{NF}-\kappa \mathrm{B}$ was significantly downregulated by Latcripin-13 domain. These results demonstrated that Latcripin-13 domain induced apoptosis and cell cycle arrest at G1 phase in the A549 cells, providing a mechanism for the antitumor effects of Latcripin-13 domain.
\end{abstract}

Correspondence to: Professor Min Huang, Department of Microbiology, Dalian Medical University, 9 Western Section, Lvshun South Road, Lvshunkou, Dalian, Liaoning 116044, P.R. China E-mail: huangminchao@163.com

Abbreviations: $\mathrm{RCC} 1$, regulator of chromosome condensation; PHD, plant homeodomain; L. edodes, Lentinula edodes; CD, circular dichroism; BLIP-II, $\beta$-lactamase-inhibitor protein II; MTT, 3-(4,5-dimethylthiazol-2-yl)-2,5-diphenyl-tetrazolium bromide

Key words: Latcripin-13 domain, RCC1, PHD, apoptosis, G0/G1 arrest, GSK3 $\beta$

\section{Introduction}

Lung cancer is one of the leading causes of cancer-related deaths worldwide. During the past decades, great advances have been made in the management of lung cancer; however, the 5-year survival rate is still less than 15\% (1). Most lung cancer patients eventually develop drug resistance following systematic surgery, chemotherapy and radiotherapy (2). Recently developed molecularly targeted therapies, such as epidermal growth factor receptor-tyrosine kinase inhibitors, have improved the survival time of some patients. Nevertheless, drug resistance is still a current challenge for molecularly targeted therapies (3). Recent studies have clearly demonstrated that natural bioactive compounds can effectively inhibit growth and proliferation, and induce apoptosis in various cancer cells, with marginal side effects. This suggests that the use of natural products is a promising alternative strategy for the treatment of lung cancer (4).

Fungal-derived chemical compounds with novel structure and biological activity are potential agents for anticancer drug development $(5,6)$. Lentinula edodes is the second most popular edible mushroom in the world market (7). It has not only been widely used as a health food for thousands of years in China, Japan and Korea, but has also become popular in nutritional and medicinal products throughout Europe and North America (8). Dried L. edodes contains carbohydrates, proteins, fiber, lipids and ash (9). As a medicinal material, L. edodes has many pharmacological activities, including antibacterial, antiviral, immunomodulatory and antitumor activities (10), but the molecular pharmacology of L. edodes remains to be determined.

In our previous studies, we found that Latcripin-13 domain, a novel protein from $L$. edodes $\mathrm{C}_{91-3}$, demonstrated tumor-suppressive activity via inducing the apoptosis of tumor cells without toxicity in normal cells (11). However the underlying molecular mechanism is largely unknown. Latcripin-13 domain belongs to the secretion-regulating guanine nucleotide exchange factor (also known as DelGEF) family, which may be involved in the secretion process. Latcripin-13 domain contains a regulator of chromosome condensation (RCC1) domain/ $\beta$-lactamase-inhibitor protein II (BLIP-II) and a plant homeodomain (PHD). RCC1 and PHD domains are involved in several key cellular processes, including nucleocytoplasmic 
transport, regulation of spindle formation, nuclear envelope reassembly at mitosis, gene transcription, cell cycle and apoptosis $(12,13)$. However, BLIP-II does share significant sequence identity with the regulator of chromosome condensation (RCC1) family of proteins. These two families are clearly related, both having a seven-bladed $\beta$-propeller structure, although they differ in the number of strands per blade; BLIP-II having three anti-parallel $\beta$-strands per blade, while RCC1 has four-stranded blades (14). BLIP-II is a secreted protein produced by the soil bacteria Streptomyces exfoliates SMF19. BLIP-II acts as a potent inhibitor of $\beta$-lactamases such as TEM-1, which is the most widespread resistance enzyme to penicillin antibiotics (15). Based on the previous study, we hypothesized that Latcripin-13 domain may induce cancer cell apoptosis by disrupting pathways important for cell cycle progression. Whether or not Latcripin-13 domain has the activity of inhibiting the $\beta$-lactamases, will be investigated in the future.

In this study, we treated human lung carcinoma A549 cells with different concentrations of Latcripin-13 domain for varying times, analyzed cell apoptosis and cell cycle progression, and explored the potential molecular mechanisms.

\section{Materials and methods}

Preparation and analysis of Latcripin-13 domain. The expression, purification and analysis of the amino acid sequence and protein structure of Latcripin-13 domain were performed as previously described (11). In brief, Latcripin-13 domain, cloned from the transcriptome of L.edodes, was expressed in E. coli Rosetta-gami (DE3) in the form of inclusion bodies. The Latcripin-13 domain was purified by Ni-His affinity chromatography with high purity and refolded by urea gradient dialysis. The amino acid sequence of Latcripin-13 protein was analyzed using the online tool ExPASy ProtParam. The protein structure of Latcripin-13 was analyzed with the circular dichroism (CD) spectra, Swiss-Model, Pfam and InterPro databases.

Cell line and cell culture. Human lung carcinoma A549 cells were obtained from the Shanghai Institute of Biochemistry and Cell Biology (Shanghai, China). The cells were maintained in RPMI-1640 medium supplemented with $10 \%$ fetal bovine serum (FBS), $100 \mathrm{ng} / \mathrm{ml}$ streptomycin and $100 \mathrm{U} / \mathrm{ml}$ penicillin at $37^{\circ} \mathrm{C}$ in a humidified atmosphere with $5 \% \mathrm{CO}_{2}$.

Cell viability assay. The effects of Latcripin-13 domain on A549 cell viability were measured using the 3-(4,5-dimethylthiazol-2-yl)-2,5-diphenyl-tetrazolium bromide (MTT) assay. Cells were treated with Latcripin-13 domain at various concentrations. After treatment for 24 or $48 \mathrm{~h}$, medium was replaced and $20 \mu \mathrm{l}$ MTT [5 $\mathrm{mg} / \mathrm{ml}$ in phosphate-buffered saline (PBS) solution] was added into each well. After incubation for $4 \mathrm{~h}$, culture supernatants were aspirated, and purple insoluble MTT product was redissolved in $150 \mu \mathrm{l}$ of dimethyl sulfoxide (DMSO). Absorbance at $562 \mathrm{~nm}$ was measured via an ELISA reader (Thermon, USA).

Nuclear staining with Hoechst 33258. The nuclear morphology of cells was evaluated using the cell-permeable
DNA dye, Hoechst 33258 . A549 cells $\left(1 \times 10^{5}\right.$ cells $\left./ \mathrm{ml}\right)$ were placed in 6-well plates containing 1,500 $\mu \mathrm{l}$ culture medium and permitted to adhere for $24 \mathrm{~h}$. Different concentrations of Latcripin-13 domain were added. After $48 \mathrm{~h}$, the supernatant was aspirated and $100 \mu \mathrm{l}$ of Hoechst 33258 was added to each well, followed by incubation at $37^{\circ} \mathrm{C}$ for $10 \mathrm{~min}$. The stained cells were observed under a fluorescence microscope at the wavelength of $340 \mathrm{~nm}$.

Cell cycle analysis. Cell cycle distribution was assayed using the Cell Apoptosis PI detection kit (KeyGen Biotech, Nanjing, China) according to the manufacturer's protocol. Briefly, $1 \times 10^{6}$ cells were harvested and washed with $1 \mathrm{X}$ buffer A after Latcripin-13 domain treatment. The cells were fixed with cold $70 \%$ ethanol for $24 \mathrm{~h}$ at $-20^{\circ} \mathrm{C}$, and then resuspended in $500 \mu \mathrm{l} 1 \mathrm{X}$ buffer $\mathrm{A}$, followed by incubation with $5 \mu \mathrm{l}$ propidium iodide (PI) for $30 \mathrm{~min}$ in the dark. After $30 \mathrm{~min}$, fluorescence-activated cells were sorted in the FACSCalibur $^{\mathrm{TM}}$ flow cytometer (BD Biosciences, San Jose, CA, USA) with excitation at $488 \mathrm{~nm}$ and detection at $620 \mathrm{~nm}$. Data were gated to exclude cellular debris. The proportions of G1, S and G2-M phase cells were calculated from the DNA content histograms.

Assay of mitochondrial membrane potential. Mitochondrial membrane potential $(\Delta \psi \mathrm{m})$ was measured using the mitochondrial membrane sensor kit containing the dye JC-1 (KeyGen Biotech) according to the manufacturer's instruction. Cells were treated with Latcripin-13 domain for $48 \mathrm{~h}$, and then harvested for flow cytometric analysis.

Western blot analysis. Protein extracts of A549 cells treated with or without Latcripin-13 domain were prepared by lysing cells in RIPA buffer on ice for $30 \mathrm{~min}$. Samples were centrifuged at $15,000 \mathrm{x} \mathrm{g}$ for $10 \mathrm{~min}$. Protein concentration was determined with the BCA protein assay (KeyGen Biotech). For each sample, $30 \mu \mathrm{g}$ /lane of protein was loaded onto $12 \%$ polyacrylamide gels and transferred to Total Blot NC membranes (Pall, USA), followed by blocking with 5\% fat-free milk and incubation with the appropriate specific primary and secondary antibodies. The antibodies used were as follows: NF- $\kappa \mathrm{B}$ (p65; ZSGB-BIO, Beijing, China); phosphorylated-GSK3 $\beta$ (S9; Bioworld Technology, Nanjing, China); GSK3 $\beta$, Bcl-2, Bax, cyclin D1, CDK4, $\beta$-actin (Proteintech, Wuhan, China); GAPDH (TransGen Biotech, Beijing, China); secondary antibody (ZSGB-BIO). Signals were detected using a chemiluminescent gel imaging system according to the manufacturer's instructions (Bio-Rad).

Caspase activation assay. Caspase- 3 , caspase- 8 and caspase- 9 activation was determined using Caspase Colorimetric assay kits (KeyGen Biotech) following the manufacturer's instructions. In brief, $2 \times 10^{6}$ cells were collected following treatment with various concentrations of Latcripin-13 domain (50, $100 \mu \mathrm{g} / \mathrm{ml}$ ) for $48 \mathrm{~h}$. After washing with PBS, cells were lysed in $50 \mathrm{ml}$ of cold lysis buffer and incubated on ice for $20 \mathrm{~min}$. The cell lysate was centrifuged at $15,000 \mathrm{rpm}$ for $10 \mathrm{~min}$ at $4^{\circ} \mathrm{C}$. Reaction buffer/dithiothreitol (DTT) was then added to the supernatant. After incubation at $37^{\circ} \mathrm{C}$ for $2 \mathrm{~h}$ with substrate DEVD-pNA, the absorbance was measured at the wavelength 
A

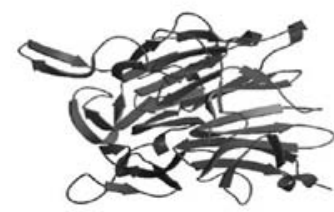

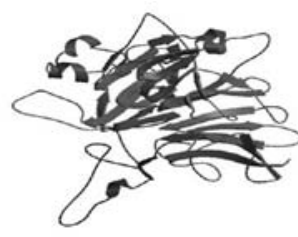

b

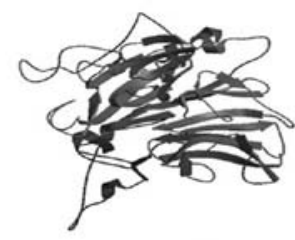

c

B

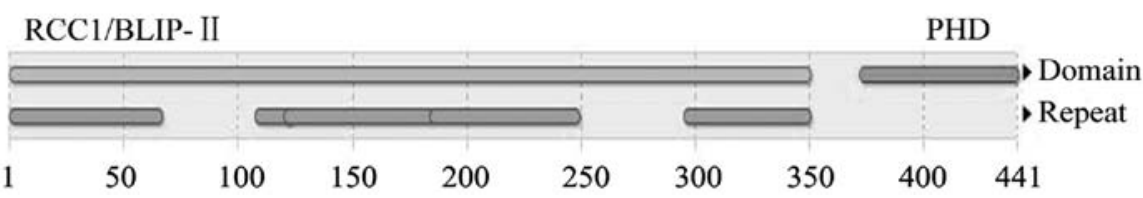

Figure 1. The model building results and InterPro databases of Latcripin-13 domain. (A) The SWISS-MODEL template library was searched with Blast and HHBlits for evolutionary related structures matching the target sequence which show the three possible model building results (a-c). (B) The InterPro databases show that Latcripin-13 domain may belong to the secretion-regulating guanine nucleotide exchange factor (also known as DelGEF) family and contain a regulator of chromosome condensation (RCC1) domain/ $\beta$-lactamase-inhibitor protein II (BLIP-II) and a plant homeodomain (PHD).

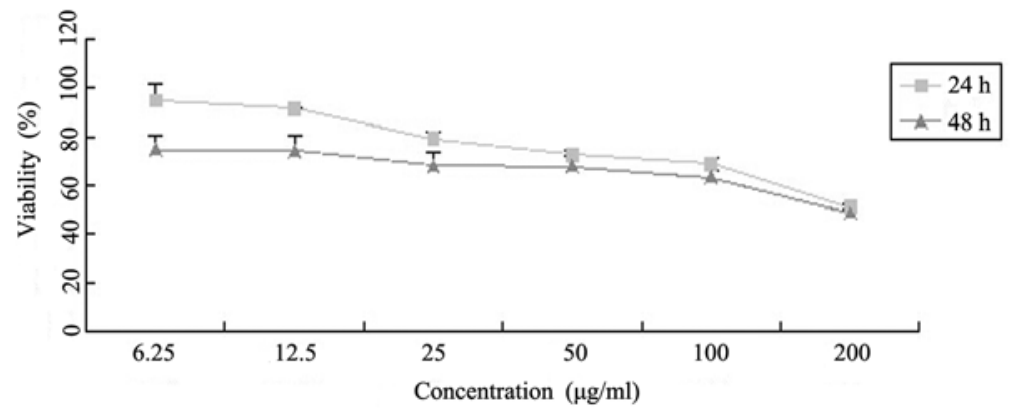

Figure 2. Latcripin-13 domain inhibits the proliferation of A549 cells. A549 cells were exposed to the indicated concentrations of Latcripin-13 domain for 24 and $48 \mathrm{~h}$. Cell viability was determined using the MTT assay. Results represent the mean \pm SD of three independent experiments.

of $405 \mathrm{~nm}$ using an ELISA microreader. Caspase-3, -8 and -9 activity was denoted as $U$ and calculated from the standard curve generated with pNA solutions of different concentrations.

Statistical analysis. All the data are presented as mean \pm standard deviations of three independent experiments. Statistical analyses were performed by one-way ANOVA using SPSS 11.0 software. Significant difference was set at $\mathrm{P}<0.05$.

\section{Results}

Preparation and properties of Latcripin-13 domain. The amino acid sequence of the Latcripin-13 domain was obtained according to the gene sequence (GenBank accession number: KF682439, the sites from 235 to 1557). The number of amino acids of Latcripin-13 domain was 441 with molecular weight of 46705.2 Da and theoretical isoelectric point of 5.07. The CD spectra of the Latcripin-13 domain exhibited a high content of $\alpha$-helix (4.7\%), $\beta$-sheets (38.7\%), turns $(21.6 \%)$ and unordered (35\%), as predicted using the Swiss-Model database. The InterPro database showed that Latcripin-13 domain belongs to the secretion-regulating guanine nucleotide exchange factor (also known as DelGEF) family containing the RCC1/BLIP-II and PHD domain. The model building results of Latcripin-13 domain by Swiss-Model database are showed in Fig. 1.
Latcripin-13 domain inhibits the proliferation of A549 cells. To assay the effects of Latcripin-13 domain on the proliferation of A549 cells, we treated A549 cells with varying concentrations of Latcripin-13 domain for 24 and $48 \mathrm{~h}$, and determined cell viability with the MTT assay. As shown in Fig. 2, Latcripin-13 domain inhibited the viability of the A549 cells in dose- and time-dependent manners.

Latcripin-13 domain induces cell cycle arrest at $G 1$ phase in A549 cells. To investigate the underlying mechanism by which Latcripin-13 domain inhibits cell proliferation of A549 cells, we analyzed the cell cycle progression following Latcripin-13 domain treatment. A549 cells were incubated with 50 or $100 \mu \mathrm{g} / \mathrm{ml}$ of Latcripin-13 domain for 24 and $48 \mathrm{~h}$. The distribution of the cell cycle was analyzed using PI staining. Treatment with 50 or $100 \mu \mathrm{g} / \mathrm{ml}$ of Latcripin-13 domain for $24 \mathrm{~h}$ led to 79.6 and $82.01 \%$, respectively, of cells in the G0/G1 phase compared with $64.53 \%$ in the control group. Moreover, 85.15 and $86.68 \%$ of cells were in $\mathrm{G} 0 / \mathrm{G} 1$ phase following treatment for $48 \mathrm{~h}$ with 50 and $100 \mu \mathrm{g} / \mathrm{ml}$, respectively (Fig. 3A). Thus, Latcripin-13 domain arrested A549 cells in the cell cycle at the $\mathrm{G} 0 / \mathrm{G} 1$ phase.

To determine the molecular mechanism underlying cell cycle arrest in the $\mathrm{G} 1$ phase by Latcripin-13 domain, the expression of G1 phase regulatory proteins, CDK4, cyclin D1, 
A
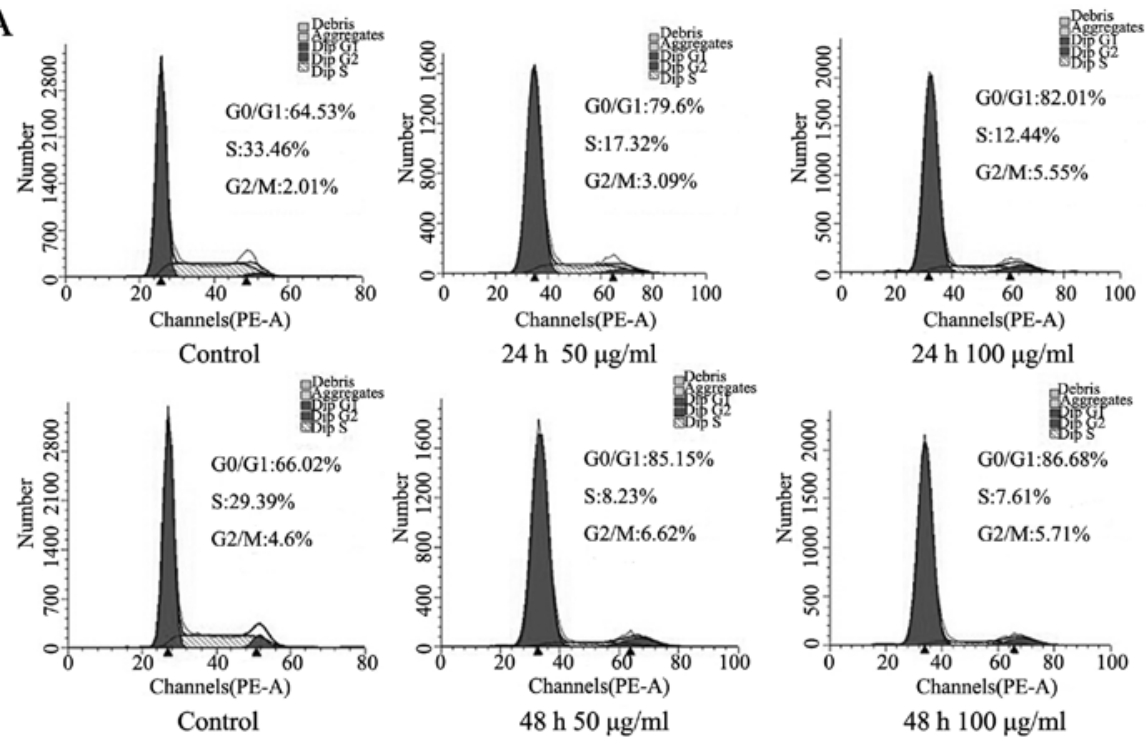

B

Control $50 \mu \mathrm{g} / \mathrm{ml} 100 \mu \mathrm{g} / \mathrm{ml}$

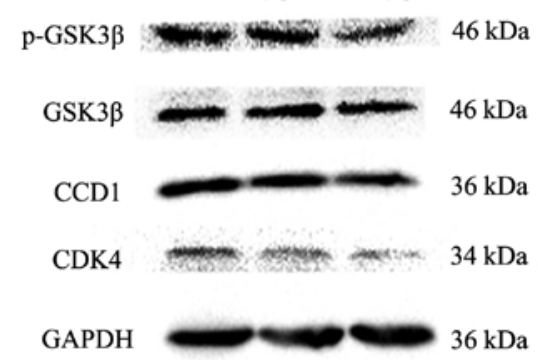

C

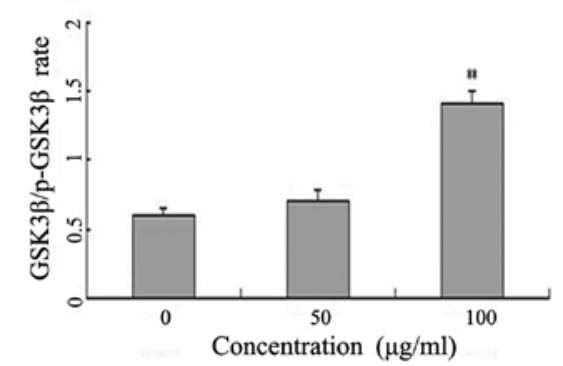

Figure 3. Cell cycle arrest by Latcripin-13 domain. (A) Changes in the cell cycle distribution in A549 cells treated with Latcripin-13 domain. Accumulation of G0/G1 phase cells was observed after treatment with Latcripin-13 domain (50 or $100 \mu \mathrm{g} / \mathrm{ml}$ for 24 and $48 \mathrm{~h}$ ). (B) The effects of Latcripin-13 domain on G1 cell-cycle regulatory proteins. G1 cell-cycle regulatory proteins, including cyclin D1, CDK4 and GSK3 $\beta /$ phosphorylated GSK3 $\beta$ were examined using western blot analyses. (C) The GSK3 $\beta /$ phosphorylated GSK3 $\beta$ ratio in cells exposed to Latcripin- 13 domain ( 50 or $100 \mu \mathrm{g} / \mathrm{ml}$ for $48 \mathrm{~h}$ ) or unexposed. ${ }^{*} \mathrm{P}<0.05,{ }^{* * *} \mathrm{P}<0.01$ compared to the controls. Data from optical density measurements were tested using one-way ANOVA.
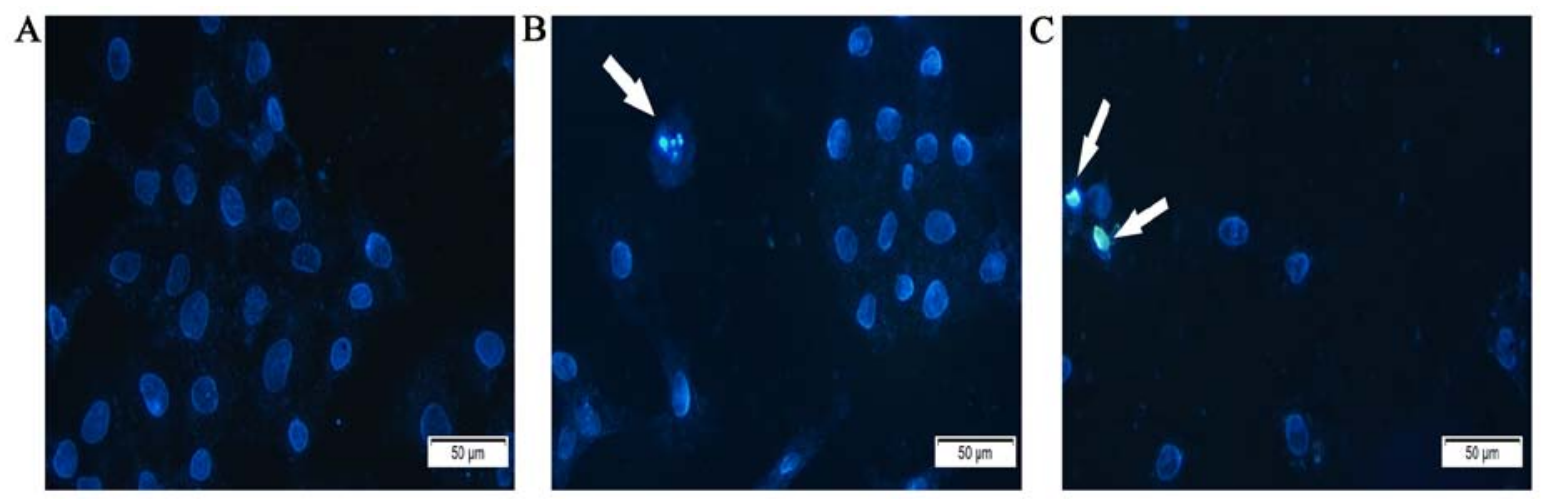

Figure 4. Fluorescence micrographs of A549 cells stained with Hoechst 33258 (x100 magnification). Cells were treated with $0 \mu \mathrm{g} / \mathrm{ml}$ (A), $50 \mu \mathrm{g} / \mathrm{ml}$ (B) or $100 \mu \mathrm{g} / \mathrm{ml}$ (C) Latcripin-13 domain for $48 \mathrm{~h}$. Latcripin-13 domain induced nuclear condensation and fragmentation.

GSK3 $\beta$ and phosphorylated GSK3 $\beta$ were examined after treatment with Latcripin-13 domain for $48 \mathrm{~h}$ by western blotting. We found that $100 \mu \mathrm{g} / \mathrm{ml}$ of Latcripin-13 domain significantly decreased cyclin D1 and CDK4, and increased the ratio of GSK3 $\beta /$ phosphorylated GSK3 $\beta$ in the A549 cells (Fig. 3B and C). These results indicated that Latcripin-13 domain arrested cell cycle at the G1 phase, at least in part by decreasing cyclin D1/CDK4 and phosphorylation of GSK3 $\beta$.

Latcripin-13 domain induces apoptosis in A549 cells. To assess whether induction of apoptosis contributed to the inhibition of cell proliferation of A549 cells by Latcripin-13 domain, 


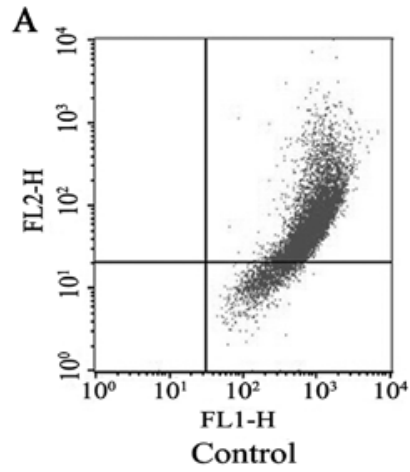

B

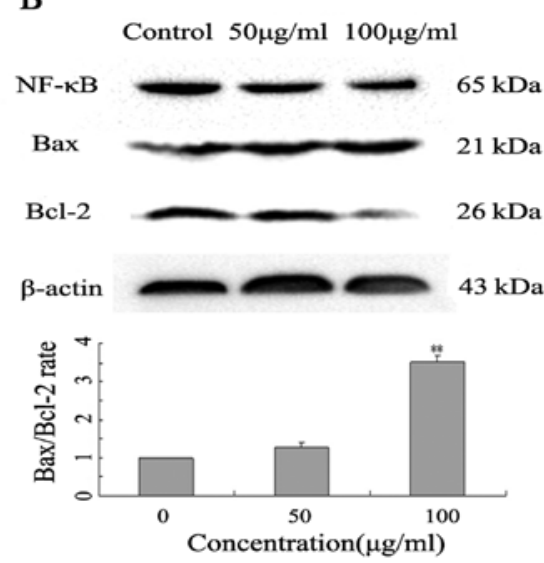

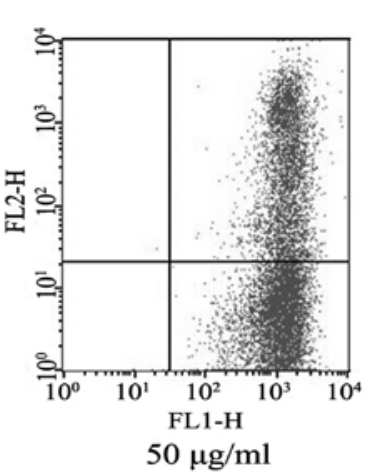

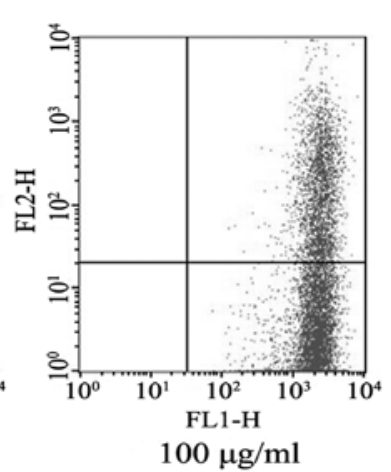

C

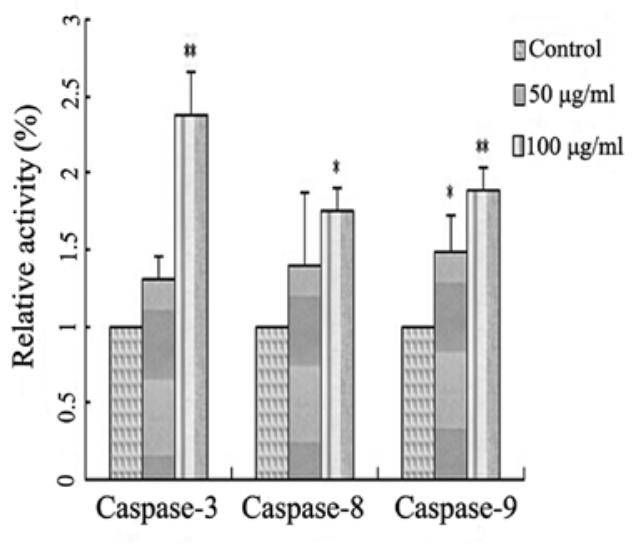

Figure 5. Latcripin-13 domain induces apoptosis by the mitochondrial-mediated pathway in A549 cells. (A) Depolarization of mitochondrial membrane potential (MMP, $\Delta \psi \mathrm{m}$ ) was examined in control A549 cells and A549 cells exposed to Latcripin-13 domain (50 or $100 \mu \mathrm{g} / \mathrm{ml}$ for $48 \mathrm{~h}$ ). Cells were stained with JC-1 and analyzed by flow cytometry. (B) Western blot analysis of NF- $\kappa \mathrm{B}, \mathrm{Bcl}-2$ and Bax expression, and the Bax/Bcl-2 ratio in the cells exposed to Latcripin-13 domain (50 or $100 \mu \mathrm{g} / \mathrm{ml}$ for $48 \mathrm{~h}$ ) or unexposed. ${ }^{*} \mathrm{P}<0.05,{ }^{* *} \mathrm{P}<0.01$ compared to the controls. Data from optical density measurements were tested using one-way ANOVA. (C) The relative activities of caspase-3, caspase- 8 and caspase-9 in A549 cells treated with Latcripin-13 domain for 48 h were higher than the relative activities in the untreated control cells.

we treated A549 cells with 0,5 or $100 \mu \mathrm{g} / \mathrm{ml}$ of Latcripin-13 domain for $48 \mathrm{~h}$ and assessed the cell morphology under a microscope following Hoechst 33258 staining. In comparison to the control, Latcripin-13 domain induced apparent nuclear fragmentation and chromatin condensation, the typical morphological characteristics of apoptotic cells (Fig. 4). These results showed that Latcripin-13 domain induced apoptosis of the A549 cells.

Latcripin-13 domain induces apoptosis by mitochondria-mediated pathway in A549 cells. To support the above observation, we evaluated the mitochondrial function of Latcripin-13 domain-treated A549 cells by measuring mitochondrial membrane potential (MMP, $\Delta \psi \mathrm{m}$ ) using the fluorochrome JC-1 and flow cytometry. A549 cells treated with Latcripin-13 domain demonstrated significant dissipation of the MMP in a concentration-dependent manner (Fig. 5A), indicating that treatment with Latcripin-13 domain led to loss of mitochondrial membrane potential in the A549 cells.

We next evaluated the anti-apoptotic proteins NF- $\kappa \mathrm{B}, \mathrm{Bcl}-2$ and the pro-apoptotic protein Bax in the Latcripin-13 domaintreated A549 cells by western blotting. Latcripin-13 domain downregulated the expression of $\mathrm{NF}-\kappa \mathrm{B}, \mathrm{Bcl}-2$, and moderately increased the expression of Bax (Fig. 5B). Quantification analysis showed that Latcripin-13 domain induced a concen- tration-dependent increase in the $\mathrm{Bax} / \mathrm{Bcl}-2$ ratio in the $\mathrm{A} 549$ cells, an indication of cell apoptosis (Fig. 5B).

To assess whether the Latcripin-13-induced apoptosis in A549 cells is caspase-dependent, caspase- $3,-8$ and -9 enzyme activity was analyzed using a Caspase Colorimetric assay. In comparison to the control, $100 \mu \mathrm{g} / \mathrm{ml}$ of Latcripin-13 domain significantly induced the activation of caspase-3 $(\mathrm{P}<0.01)$, caspase- 8 and caspase- $9(\mathrm{P}<0.05)$ (Fig. 5C).

\section{Discussion}

In the present study, we demonstrated that Latcripin-13 domain inhibited proliferation and induced G1 phase cell cycle arrest of the A549 cells. The cell cycle arrest was accompanied by decreased cyclin D1 and CDK4, and an increased ratio of GSK3 $\beta$ /phosphorylated GSK3 $\beta$. Importantly, Latcripin-13 domain induced the apoptosis of the A549 cells, as demonstrated by loss of mitochondrial membrane potential, increase in the Bax/Bcl-2 ratio and activation of the caspases. Our results indicated that Latcripin-13 domain arrested cell cycle progression and induced apoptosis in lung carcinoma A549 cells, suggesting that Latcripin-13 domain is a potential agent for the treatment of lung cancer.

Uncontrolled regulation of the cell cycle, leading to unrestrained cell proliferation, is a hallmark of cancer. Normal cell cycle progression requires the sequential expression of cyclins, 
resulting in the activation of the cyclin-dependent kinases (CDKs) to phosphorylate target proteins (16). Cyclin D1 is a positive cell-cycle regulator necessary for the transition of cells from G1 to S phase. Cyclin D1 is expressed relatively early in the G1 phase as a crucial control of the G1 checkpoint of the cell cycle, after which cyclin D1/CDK4/6 forms a complex that is important in cell cycle regulation by retinoblastoma $(\mathrm{Rb})$ phosphorylation (17-19). Overexpression of cyclin D1 is among the most commonly observed alterations in human malignant disorders. In this study, we found that Latcripin-13 domain inhibited proliferation and arrested A549 cells in G1 phase, accompanied by a decrease in cyclin D1 expression. These results suggest that Latcripin-13 domain may inhibit the growth of cancer cells by decreasing cyclin D1.

Cyclin D1 is overexpressed in most cancers (20). Genetic mutations or aberrant control of cyclin D1 expression contribute to cyclin D1 upregulation and accelerated G1 to S phase transition (21). GSK-3 is a serine-threonine kinase involved in a variety of physiologic functions such as glycogen metabolism, gene expression and apoptosis (22-24). Moreover, GSK-3 $\beta$ plays a key role in the regulation of cyclin D1 by both regulating cyclin D1 mRNA transcription and ubiquitin-dependent proteolysis of cyclin D1 protein (25). Accordingly, GSK-3 $\beta$ is implicated in the pathogenesis of a number of diseases, including diabetes, bipolar disorder, Alzheimer's disease, heart failure and cancer (26-29). Proteasome-dependent degradation of cyclin D1 is triggered by GSK-3 $\beta$-mediated phosphorylation at threonine 286 (Thr286), which targets cyclin D1 for ubiquitination and proteolytic destruction $(30,31)$. Our study showed that with an increasing concentration of Latcripin-13 domain, the GSK $3 \beta /$ phosphorylated GSK $3 \beta$ ratio increased. Our results suggest that Latcripin-13 domain may inhibit the G1 to S phases transition of A549 cells via a GSK3 $\beta$-cyclin D1 signaling pathway.

Cell apoptosis is characterized by cytoplasmic shrinkage, chromatin condensation and DNA fragmentation $(32,33)$. As shown in Fig. 2, the growth of A549 cells was inhibited by Latcripin-13 domain in a dose- and time-dependent manner. Fluorescence microscopy of cells stained with the DNA-binding dye Hoechst 33258 revealed that Latcripin-13 peptide treatment resulted in significant cell shrinkage and obvious chromatin condensation (Fig. 4).

Cell apoptosis is controlled by the mitochondrial Fas signaling pathways (34). Dysfunction of mitochondria results in a permeabilization of the outer membrane and concomitant release of mitochondrial apoptotic components into the cytosol, leading to caspase activation (35). Mitochondrial membrane permeability is controlled by a balance of pro- and anti-apoptotic proteins, including $\mathrm{Bax}$ and $\mathrm{Bcl}-2$. In addition, apoptosis in cancer cells is mediated by cell surface death receptors, activation of which leads to activated caspase- 8 and downstream caspases, such as caspase-3 (36). Activated caspase- 8 can also cleave and stimulate Bid protein, which further promotes caspase-9 activation (37,38). Caspase-3, a downstream effector of both apoptosis pathways, is activated to regulate the caspase signaling cascade, eventually inducing apoptosis $(39,40)$. Thus, these three caspases play important roles in the induction, transduction and amplification of intracellular apoptotic signals (41). Our results showed that Latcripin-13 domain decreased MMP, accompanied by an increase in Bax, but a decrease in Bcl-2. In addition, Latcripin-13 domain at $100 \mu \mathrm{g} / \mathrm{ml}$ significantly activated caspase-3, -8 and -9 in A549 cells. Importantly, NF- $\kappa \mathrm{B}$ was also downregulated by Latcripin-13 domain (Fig. 5B). RCC1 is a eukaryotic nuclear protein that acts as a guanine nucleotide exchange factor for Ran, a member of the Ras GTPase family. RCC1 mediates a Ran-GTP gradient necessary for the regulation of spindle formation and nuclear assembly during mitosis, as well as for the transport of macromolecules across the nuclear membrane during interphase (42). The nuclear RanGTP level is diminished during the early stages of apoptosis, which correlates with immobilization of RCC1 on the chromosomes. Nuclear localization signal (NLS)-containing proteins that transport to the nucleus have been limited, including NF-kB-p65, which has important roles in rescuing cells from apoptosis. Wong et al has reported that RCC1 reads the histone code created by caspase-activated Mst1 to initiate apoptosis by reducing the level of RanGTP in the nucleus (43). Therefore, we propose that Latcripin-13 domain may reduce the concentration of nuclears RanGTP and recruit the Fas-associated via death domain (FADD) to bind to death receptors, which in turn activates caspase- 8 to inhibit NF- $\mathrm{\kappa B}$ signaling.

In conclusion, our data indicate that Latcripin-13 domain inhibits the proliferation of A549 cells via G1 cell cycle arrest and also inhibits the mitochondrial-mediated pathway. In addition, Latcripin-13 domain induces apoptosis through caspase -8 and NF- $\kappa$ B signaling. These findings provide further mechanistic evidence of the anticancer activity of Latcripin-13 domain.

\section{Acknowledgements}

This study was financially supported by the National Natural Science Foundation of China (no. 81472836).

\section{References}

1. Jahangeer S, Forde P, Soden D and Hinchion J: Review of current thermal ablation treatment for lung cancer and the potential of electrochemotherapy as a means for treatment of lung tumors. Cancer Treat Rev 39: 862-871, 2013.

2. Wu CY, Hu HY, Pu CY, Huang N, Shen HC, Li CP and Chou YJ: Pulmonary tuberculosis increases the risk of lung cancer: A population-based cohort study. Cancer 117: 618-624, 2011.

3. Kerkentzes K, Lagani V, Tsamardinos I, Vyberg M and Røe OD: Hidden treasures in 'ancient' microarrays: gene-expression portrays biology and potential resistance pathways of major lung cancer subtypes and normal tissue. Front Oncol 4: 251, 2014.

4. Surh YJ: Cancer chemoprevention with dietary phytochemicals. Nat Rev Cancer 3: 768-780, 2003.

5. Long BH and Fairchild CR: Paclitaxel inhibits progression of mitotic cells to G1 phase by interference with spindle formation without affecting other microtubule functions during anaphase and telephase. Cancer Res 54: 4355-4361, 1994.

6. Patel S and Goyal A: Recent developments in mushrooms as anticancer therapeutics: A review. Biotech 2: 1-15, 2012.

7. Hadeler H: Medicinal Mushrooms You Can Grow. Cariaga Publishing House, 1995.

8. Lee KH, Morris-Natschke SL, Yang X, Huang R, Zhou T, Wu SF, Shi $\mathrm{Q}$ and Itokawa $\mathrm{H}$ : Recent progress of research on medicinal mushrooms, foods, and other herbal products used in traditional Chinese medicine. J Tradit Complement Med 2: 84-95, 2012.

9. Xu X, Yan H, Tang J, Chen J and Zhang X: Polysaccharides in Lentinus edodes: Isolation, structure, immunomodulating activity and future prospective. Crit Rev Food Sci Nutr 54: 474-487, 2014. 
10. Bisen PS, Baghel RK, Sanodiya BS, Thakur GS and Prasad GB: Lentinus edodes: A macrofungus with pharmacological activities. Curr Med Chem 17: 2419-2430, 2010.

11. Wang J, Zhong M, Liu B, Sha L, Lun Y, Zhang W, Li X, Wang X, Cao J, Ning A, et al: Expression and functional analysis of novel molecule - Latcripin-13 domain from Lentinula edodes $\mathrm{C}_{91-3}$ produced in prokaryotic expression system. Gene 555: 469-475, 2015.

12. Bienz M: The PHD finger, a nuclear protein-interaction domain. Trends Biochem Sci 31: 35-40, 2006.

13. Yamaguchi R and Newpor J: A role for Ran-GTP and Crm1 in blocking re-replication. Cell 113: 115-125, 2003.

14. Lim D, Park HU, De Castro L, Kang SG, Lee HS, Jensen S, Lee KJ and Strynadka NCJ: Crystal structure and kinetic analysis of beta-lactamase inhibitor protein-II in complex with TEM-1 beta-lactamase. Nat Struct Biol 8: 848-852, 2001.

15. Fryszczyn BG, Adamski CJ, Brown NG, Rice K, Huang W and Palzkill T: Role of $\beta$-lactamase residues in a common interface for binding the structurally unrelated inhibitory proteins BLIP and BLIP-II. Protein Sci 23: 1235-1246, 2014.

16. Bernardi A, Frozza RL, Hoppe JB, Salbego C, Pohlmann AR, Battastini AM and Guterres SS: The antiproliferative effect of indomethacin-loaded lipid-core nanocapsules in glioma cells is mediated by cell cycle regulation, differentiation, and the inhibition of survival pathways. Int J Nanomedicine 8: 711-728, 2013

17. Blagosklonny MV and Pardee AB: The restriction point of the cell cycle. Cell Cycle 1: 103-110, 2002.

18. Giacinti $\mathrm{C}$ and Giordano A: RB and cell cycle progression. Oncogene 25: 5220-5227, 2006.

19. Caldon CE, Sutherland RL and Musgrove E: Cell cycle proteins in epithelial cell differentiation: Implications for breast cancer. Cell Cycle 9: 1918-1928, 2010.

20. Pines J: Four-dimensional control of the cell cycle. Nat Cell Biol 1: E73-E79, 1999.

21. Hsieh TC, Yang CJ, Lin CY, Lee YS and Wu JM: Control of stability of cyclin D1 by quinone reductase 2 in CWR22Rv1 prostate cancer cells. Carcinogenesis 33: 670-677, 2012.

22. Embi N, Rylatt DB and Cohen P: Glycogen synthase kinase-3 from rabbit skeletal muscle. Separation from cyclic-AMP-dependent protein kinase and phosphorylase kinase. Eur J Biochem 107: 519-527, 1980

23. Troussard AA, Tan C, Yoganathan TN and Dedhar S: Cell-extracellular matrix interactions stimulate the AP-1 transcription factor in an integrin-linked kinase- and glycogen synthase kinase 3-dependent manner. Mol Cell Biol 19: 7420-7427, 1999.

24. Turenne GA and Price BD: Glycogen synthase kinase 3 beta phosphorylates serine 33 of p53 and activates p53's transcriptional activity. BMC Cell Biol 2: 12, 2001.

25. Takahashi-Yanaga F and Sasaguri T: GSK-3beta regulates cyclin D1 expression: A new target for chemotherapy. Cell Signal 20: 581-589, 2008.

26. Haq S, Choukroun G, Kang ZB, Ranu H, Matsui T, Rosenzweig A, Molkentin JD, Alessandrini A, Woodgett J, Hajjar R, et al: Glycogen synthase kinase-3beta is a negative regulator of cardiomyocyte hypertrophy. J Cell Biol 151: 117-130, 2000.
27. Antos CL, McKinsey TA, Frey N, Kutschke W, McAnally J, Shelton JM, Richardson JA, Hill JA and Olson EN: Activated glycogen synthase-3 beta suppresses cardiac hypertrophy in vivo. Proc Natl Acad Sci USA 99: 907-912, 2002.

28. van de Schans VA, van den Borne SW, Strzelecka AE, Janssen BJ, van der Velden JL, Langen RC, Wynshaw-Boris A, Smits JF and Blankesteijn WM: Interruption of Wnt signaling attenuates the onset of pressure overload-induced cardiac hypertrophy. Hypertension 49: 473-480, 2007.

29. Martinez A, Castro A, Dorronsoro I and Alonso M: Glycogen synthase kinase 3 (GSK-3) inhibitors as new promising drugs for diabetes, neurodegeneration, cancer, and inflammation. Med Res Rev 22: 373-384, 2002.

30. Diehl JA, Zindy F and Sherr CJ: Inhibition of cyclin D1 phosphorylation on threonine-286 prevents its rapid degradation via the ubiquitin-proteasome pathway. Genes Dev 11: 957-972, 1997.

31. Diehl JA, Cheng M, Roussel MF and Sherr CJ: Glycogen synthase kinase-3beta regulates cyclin D1 proteolysis and subcellular localization. Genes Dev 12: 3499-3511, 1998.

32. Lawen A: Apoptosis - an introduction. Bioessays 25: 888-896, 2003.

33. Robertson JD and Orrenius S: Molecular mechanisms of apoptosis induced by cytotoxic chemicals. Crit Rev Toxicol 30: 609-627, 2000

34. Zimmermann KC, Bonzon $C$ and Green DR: The machinery of programmed cell death. Pharmacol Ther 92: 57-70, 2001.

35. Jourdan M, Reme T, Goldschmidt H, Fiol G, Pantesco V, De Vos J, Rossi JF, Hose D and Klein B: Gene expression of anti- and pro-apoptotic proteins in malignant and normal plasma cells. Br J Haematol 145: 45-58, 2009.

36. Hu W and Kavanagh JJ: Anticancer therapy targeting the apoptotic pathway. Lancet Oncol 4: 721-729, 2003.

37. Gupta S: Molecular steps of death receptor and mitochondrial pathways of apoptosis. Life Sci 69: 2957-2964, 2001.

38. Jin Z and El-Deiry WS: Overview of cell death signaling pathways. Cancer Biol Ther 4: 139-163, 2005.

39. Lei JC, Yu JQ, Yin Y, Liu YW and Zou G: Alantolactone induces activation of apoptosis in human hepatoma cells. Food Chem Toxicol 50: 3313-3319, 2012.

40. Zhang Q, Wu J, Hu Z and Li D: Induction of HL-60 apoptosis by ethyl acetate extract of Cordyceps sinensis fungal mycelium. Life Sci 75: 2911-2919, 2004

41. Ola MS, Nawaz M and Ahsan $\mathrm{H}$ : Role of Bcl-2 family proteins and caspases in the regulation of apoptosis. Mol Cell Biochem 351: 41-58, 2011.

42. Makde RD, England JR, Yennawar HP and Tan S: Structure of RCC1 chromatin factor bound to the nucleosome core particle. Nature 467: 562-566, 2010.

43. Wong CH, Chan H, Ho CY, Lai SK, Chan KS, Koh CG and Li HY: Apoptotic histone modification inhibits nuclear transport by regulating RCC1. Nat Cell Biol 11: 36-45, 2009. 